\title{
Recent Books and Journals Articles in Public Opinion, Survey Methods, Survey Statistics, Big Data, Data Science, and User Experience Research. 2020 Update
}

\author{
Mario Callegaro 1 (1) \\ ${ }^{1}$ Google Cloud, London \\ Keywords: New books 2020 \\ https://doi.org/10.29115/SP-2021-0014
}

Survey Practice

\begin{abstract}
Welcome to the 13th edition of this column on recent books and journal articles in the field of public opinion, survey methods, survey statistics, Big Data, data science and user experience research. After a hiatus due to the pandemic which affected my productivity, I am publishing this 2020 update.

Special issues of journals have a space in this article because, in my view, they are like edited books. I also added review papers from the journal series of Annual Reviews because these papers are seminal state of the art writeups, a mini book, if you wish on a specific subject.
\end{abstract}

Welcome to the 13th edition of this column on recent books and journal articles in the field of public opinion, survey methods, survey statistics, Big Data, data science and user experience research. After a hiatus due to the pandemic which affected my productivity, I am publishing this 2020 update.

Special issues of journals have a space in this article because, in my view, they are like edited books. I also added review papers from the journal series of Annual Reviews because these papers are seminal state of the art writeups, a mini book, if you wish on a specific subject.

This article is an update of the 2019 article. Like the previous year, the books are organized by topic; this should help the readers to focus on their interests.

You will note that I use very broad definitions of public opinion, survey methods, survey statistics, Big Data, data science, and user experience research. This is because there are many books published in different outlets that can be very useful to the readers of Survey Practice, even if they do not come from traditional sources of survey content.

It is unlikely I have exhaustively listed all new books in each subcategory; I did my best scouting different resources and websites, but I take full responsibility for any omissions. The list is also focused only on books published in the English language and available for purchase (as an ebook or in print) at the time of this review (October 2021) and with the copyright year of 2020. Books are listed based on the relevance to the topic, and no judgment is made in terms of quality of the content. We let the readers do so.

If you want to send information for the next issue, please send it to surveypractice.new.books@gmail.com. 


\section{Journals special issues}

Journal of Empirical Research on Human Research Etbics published a social issue on: "Ethical Issues in Social Media Research. Volume 15, Issue 1-2, 2020.

Journal of The Academy of Marketing Science published a special issue on: "Generalizations in Marketing: Systematic Reviews and Meta-Analyses". Volume 48, Issue 3, 2020.

Journal of the Royal Statistical Society, Series A. published a special issue on: "Causal inference from non-experimental studies: challenges, developments and applications”. Volume 183, Issue 4, 2020.

Journal of Official Statistics published a special issue on: "Nonresponse". Volume 36, Issue 3, 2020.

Journal of Survey Statistics and Methodology published a special issue on: "Recent Advances in Probability-Based and Nonprobability Survey Research" Volume 8, Issue 1, 2020.

Public Opinion Quarterly published a special issue on: "Public Opinion and Political Communication in a Changing Information Environment" Volume 84, Issue S1, 2020.

Social Science Computer Review published a special issue on: "Integrating Survey Data and Digital Trace Data" Volume 38 Issue 5, 2020.

Statistical Journal of the IAOS published a social issue on: "Official Statistics in Africa”. Volume 35, No S1, 2020.

Survey Methods. Insights from the Field published a special issue on: "Advancements in Online and Mobile Survey Methods" 2020.

Survey Methods. Insights from the Field published a special issue on: "Fieldwork Monitoring Strategies for Interviewer-Administered Surveys” 2020.

Survey Research Methods published a special issue on: "Survey Research Methods during the COVID-19 Crisis". Volume 14, No 2, 2020.

Survey Research Methods published a special issue on: "Measurement Invariance: Testing for It and Explaining Why It is Absent". Volume 14, No 4, 2020.

\section{Relevant to our topics these are the reviews published recently}

Cramer, Katherine. 2020. "Understanding the Role of Racism in Contemporary Us Public Opinion.” Annual Review of Political Science 23 (1): 153-169.

Edelmann, Achim, Tom Wolff, Danielle Montagne, and Christopher A. Bail. 2020. "Computational Social Science and Sociology." Annual Review of Sociology 46 (1): 61-81. 
Marsden, Peter V., Tom W. Smith, and Michael Hout. 2020. "Tracking Us Social Change over a Half-Century: The General Social Survey at Fifty.” Annual Review of Sociology 46 (1): 109-134.

Naoi, Megumi. 2020. "Survey Experiments in International Political Economy: What We (Don't) Know about the Backlash against Globalization.” Annual Review of Political Science 23 (1): 333-156.

Pfeffer, Fabian T., Paula Fomby, and Noura Insolera. 2020. "The Longitudinal Revolution: Sociological Research at the 50-Year Milestone of the Panel Study of Income Dynamics.” Annual Review of Sociology 46 (1): 83-108.

Schaeffer, Nora Cate, and Jennifer Dykema. 2020. "Advances in the Science of Asking Questions.” Annual Review of Sociology 46 (1): 37-60.

Vanderplas, Susan, Dianne Cook, and Heike Hofmann. 2020. "Testing Statistical Charts: What Makes a Good Graph?" Annual Review of Statistics and Its Application 7 (1): 61-88.

\section{Public Opinion books}

Campbell, W. Joseph. 2020. Lost in a Gallup: Polling Failure in U.S. Presidential Elections. Oakland, CA: University of California Press.

Clark, Richard L., Kelly N. Foster, Benjamin F. Radcliff, and Samuel J. Best, eds. 2020. Polling America. An Encyclopedia of Public Opinion. 2nd ed. 2 vols. Santa Barbara, CA: Greenwood.

Forsberg, Ole J. 2020. Understanding Elections through Statistics: Polling, Prediction, and Testing. Boca Raton, FL: CRC Press.

\section{Survey and Research Methods books}

Alderson, Priscilla, and Virginia Morrow. 2020. The Ethics of Research with Children and Young People: A Practical Handbook. 2nd ed. Thousand Oaks, CA: Sage.

Billett, Paulina, Matt Hart, and Dona Martin, eds. 2020. Complexities of Researching with Young People. London: Routledge.

Brenner, Philip S., ed. 2020. Understanding Survey Methodology: Sociological Theory and Applications. Frontiers in Sociology and Social Research. Cham, Switzerland: Springer.

Corti, Louise, Veerle Van den Eynden, Libby Bishop, and Matthew Woollard. 2020. Managing and Sharing Research Data: A Guide to Good Practice. 2nd ed. Thousand Oaks, CA: Sage.

Davis, Joel J. 2020. Crafting Superior Surveys and Survey Questions: A Handson Approach. Independently published. 
Donnelly, Francis P. 2020. Exploring the U.S. Census: Your Guide to America's Data. Los Angeles: Sage.

Grønmo, Sigmund. 2020. Social Research Methods: Qualitative, Quantitative and Mixed Methods Approaches. Thousand Oaks, CA: Sage.

Hammond, Michael, and Jerry Wellington. 2020. Research Methods: The Key Concepts. 2nd ed. New York: Routledge.

Hoogeveen, Johannes, and Utz Pape, eds. 2020. Data Collection in Fragile States: Innovations from Africa and Beyond. Cham, Switzerland: Palgrave Macmillan.

Kviz, Frederick J. 2020. Conducting Health Research: Principles, Process, and Methods. Los Angeles: Sage.

McClure, Kelly S. 2020. Selecting and Describing Your Research Instruments. Washington D.C.: American Psychological Association.

Miller, Leslie A., and Robert L. Lovler. 2020. Foundations of Psychological Testing: A Practical Approach. 6th ed. Los Angeles: Sage.

Mukherjee, Shyama Prasad. 2020. A Guide to Research Methodology: An Overview of Research Problems, Tasks and Methods. Boca Raton, FL: CRC Press.

Olson, Kristen, Jolene D. Smyth, Jennifer Dykema, Allyson L. Holbrook, Frauke Kreuter, Brady T. West, Jolene D. Smyth, et al., eds. 2020. Interviewer Effects from a Total Survey Error Perspective. Boca Raton, FL: CRC Press.

Privitera, Gregory J. 2019. Research Methods for the Behavioral Sciences. 3rd ed. Los Angeles: Sage.

Schouten, Barry, Andy Peytchev, and James Wagner. 2020. Adaptive Survey Design. Boca Raton, FL: CRC Press.

Sullivan, Teresa A. 2020. Census 2020: Understanding the Issues. Cham, Switzerland: Springer.

Thomas, Nicola. 2020. Get Your Data from Social Media: Little Quick Fix. London: Sage.

Walby, Kevin, and Alex Luscombe, eds. 2020. Freedom of Information and Social Science Research Design. New York: Routledge.

\section{Survey statistics}

Bonifay, Wes. 2020. Multidimensional Item Response Theory. Los Angeles: Sage.

Crowder, Martin J. J, and David J. Hand. 2020. Analysis of Repeated Measures. Boca Raton, FL: CRC Press. 
Dickinson Gibbons, Jean, and Subhabrata Chakraborti. 2020. Nonparametric Statistical Inference. Boca Raton, FL: CRC Press.

Finch, W. Holmes. 2020. Exploratory Factor Analysis. Los Angeles: Sage.

Fox, John. 2020. Regression Diagnostics: An Introduction. 2nd ed. Thousand Oaks, California: Sage.

Garson, George David. 2020. Multilevel Modeling: Applications in STATA®, $I B M \AA S P S S \AA, S A S \circledR, R, \sigma^{2} H L M^{T M}$. Thousand Oaks, CA: Sage.

Gill, Jefferson M., and Silvia Michelle Torres Pacheco. 2020. Generalized Linear Models: A Unified Approach. 2nd ed. Thousand Oaks, CA: Sage.

Heck, Ronald, and Scott L. Thomas. 2020. An Introduction to Multilevel Modeling Techniques: MLM and SEM Approaches. 4th ed. New York: Routledge.

Kalton, Graham. 2020. Introduction to Survey Sampling. 2nd ed. Thousand Oaks, CA: SAGE Publications, Inc.

Kolassa, John E. 2020. An Introduction to Nonparametric Statistics. Boca Raton, FL: CRC Press.

Luke, Dr Douglas A. 2020. Multilevel Modeling. 2nd ed. Los Angeles: Sage.

Schmid, Christopher H., Theo Stijnen, Ian White, Theo Stijnen, and Ian White, eds. 2020. Handbook of Meta-Analysis. Boca Raton, FL: CRC Press.

Schoot, Rens van de, and Milica Miočević, eds. 2020. Small Sample Size Solutions: A Guide for Applied Researchers and Practitioners. New York: Routledge.

Schwarz, Jason S., Chris Chapman, and Elea McDonnell Feit. 2020. Python for Marketing Research and Analytics. Cham, Switzerland: Springer.

Shou, Yiyun, and Michael Smithson. 2020. Generalized Linear Models for Bounded and Limited Quantitative Variables. Los Angeles: Sage.

Sijtsma, Klaas. 2020. Measurement Models for Psychological Attributes: Classical Test Theory, Factor Analysis, Item Response Theory, and Latent Class Models. Boca Raton, FL: CRC Press.

Silva, Castanho Bruno, Manuel Constantin Bosancianu, and Littvay Levente. 2020. Multilevel Structural Equation Modeling. Thousand Oaks, CA: Sage.

Silvia, Paul. 2020. Select a Sample: Little Quick Fix. Thousand Oaks, CA: Sage. Tille, Yves. 2020. Sampling and Estimation from Finite Populations. Hoboken, NJ: Wiley. 
Verma, J. P., and Priyam Verma. 2020. Determining Sample Size and Power in Research Studies: A Manual for Researchers. Gateway East: Springer Singapore.

Westfall, Peter H., and Andrea L. Arias. 2020. Understanding Regression Analysis. A Conditional Distribution Approach. Boca Raton, FL: CRC Press.

Wu, Changbao, and Mary E. Thompson. 2020. Sampling Theory and Practice. ICSA Book Series in Statistics. Cham, Switzerland: Springer.

\section{Big Data, Data Science, Social media and other relevant books}

Bell, Andrew, Todd Hartman, Aneta Piekut, Alasdair Rae, and Mark Taylor. 2020. Making Sense of Data in the Media. Thousand Oaks, CA: Sage.

Feigenbaum, Anna, and Aria Alamalhodaei. 2020. The Data Storytelling Workbook. New York: Routledge.

Foster, Ian, Rayid Ghany, Jarmin Ron S., Frauke Kreuter, and julia Lane, eds. 2020. Big Data and Social Science: Data Science Methods and Tools for Research and Practice. 2nd ed. Boca Raton, FL: CRC Press.

Jemielniak, Dariusz. 2020. Thick Big Data: Doing Digital Social Sciences. Oxford: Oxford University Press.

Kohavi, Ron, Diane Tang, and Ya Xu. 2020. Trustworthy Online Controlled Experiments: A Practical Guide to A/B Testing. Cambridge, MA: Cambridge University Press.

Nelakurthi, Arun Reddy, and Jingrui He. 2020. Social Media Analytics for User Behavior Modeling: A Task Heterogeneity Perspective. Boca Raton, FL: CRC Press.

Vowels, Susan A., and Katherine Leaming Goldberg. 2020. Teaching Data Analytics: Pedagogy and Program Design. Boca Raton, FL: CRC Press.

Woo, Sang Eun, Louis Tay, and Robert W. Proctor, eds. 2020. Big Data in Psychological Research. Washington D.C.: American Psychological Association.

\section{User Experience Research books}

Voil, Nick de. 2020. User Experience Foundations. London: BCS, The Chartered Institute for IT. 